\title{
Renal Denervation for Refractory Hypertension - Technical Aspects, Complications and Radiation Exposure
}

\author{
Renale Denervation bei therapierefraktärem Hypertonus - technische Aspekte, \\ Komplikationen und Strahlenexposition
}

Authors

Affiliations
C. Scheurig-Muenkler ${ }^{1}$, W. Weiss² ${ }^{2}$ E. Foert ${ }^{3}$, M. Toelle², M. van der Giet ${ }^{2}$, T. J. Kröncke' ${ }^{1}$, W. Zidek ${ }^{2}$, M.-J. Powerski ${ }^{1}$

Radiologie, Charité Universitätsmedizin Berlin

Nephrologie, Charité Universitätsmedizin Berlin

Radiologie, DRK Klinikum Berlin Mitte, Berlin
Key words

- renal arteries

- ablation procedures

- hypertension

- denervation

- radiation dose

eingereicht 31.10 .2012

akzeptiert $\quad 17.1 .2013$

Bibliography

Dol http://dx.doi.org/

10.1055/s-0032-1330715

Published online: 7.3.2013

Fortschr Röntgenstr 2013; 185: 550-557 @ Georg Thieme

Verlag KG Stuttgart · New York . ISSN 1438-9029

\author{
Correspondence \\ Herr Dr. Christian Scheurig- \\ Muenkler \\ Radiologie, Charité \\ Universitätsmedizin Berlin \\ Augustenburger Platz 1 \\ 13353 Berlin \\ Germany \\ Tel.: ++49/30/450557002 \\ Fax: ++49/30/4507553928 \\ Christian.Scheurig@charite.de
}

\section{Zusammenfassung \\ $\nabla$}

Ziel: Bewertung eingriffsrelevanter technischer Details, der Komplikationen sowie der Strahlenexposition der Renalen Denervation (RDN) in der Behandlung des therapierefraktären Hypertonus unter Verwendung des Medtronic-Symplicity ${ }^{\circledR}$ Systems.

Material und Methoden: Dreiundfünfzig konsekutive Patienten wurden mittels RDN behandelt. Zahl der Ablationen pro Arterie, Eingriffsdauer (PT), Durchleuchtungszeit (FT), Dosis-FlächenProdukt (DAP) sowie eingriffsbezogene Komplikationen wurden dokumentiert. Die Strahlendosis wurde zusätzlich zwischen adipösen (BodyMass-Index $\geq 30 \mathrm{~kg} / \mathrm{m}^{2}$ ) und nicht adipösen Patienten verglichen.

Ergebnisse: Die bilaterale RDN war in 50/53 (94\%) Fällen möglich, mit einem Minimum von 4 Ablationen pro Arterie bei 33/50 (66\%) Patienten. Im Mittel erfolgten rechts 5,4 (Spannweite R: 2-13) und links 4,3 (R: 1 -10) Ablationen. FT und DAP nahmen im Verlauf der ersten 12 Eingriffe signifikant ab und erreichten ein Gleichgewicht mit einer medianen FT von 11,2 min (R: 7,5-27) und einem medianen DAP von $4796 \mathrm{cGy} \times \mathrm{cm}^{2}$ (R: 1076 - 21371), was einer geschätzten effektiven Dosis von 15,7 mSv entspricht. Die PT betrug im Median 57 Minuten (R: 40 - 70). Adipöse Patienten erhielten eine 3,3-fach höhere Strahlendosis $(p<0,001)$. Wir beobachteten jeweils einmalig und ohne bleibende Schäden einen ausgeprägten Spasmus sowie eine drohende Atemdepression. Schlussfolgerung: In den Händen eines erfahrenen Interventionalisten zeigt die RDN eine kurze Lernkurve und ein niedriges Risikoprofil. Die Strahlendosis ist nicht höher als bei sonstigen Interventionen an den Nierenarterien, steigt jedoch beträchtlich bei adipösen Patienten, die einen großen Prozentsatz der betroffenen Patienten mit therapierefraktärem Hypertonus ausmachen.

\section{Abstract \\ $\nabla$}

Purpose: To analyze procedural details, complications and radiation exposure in renal denervation (RDN) using the Medtronic Symplicity ${ }^{\circledR}$ device in the treatment of refractory hypertension.

Materials and Methods: Fifty three consecutive patients underwent RDN. The number of ablations per artery, peri-procedural complications, procedure time (PT), fluoroscopy time (FT), dosearea product (DAP) and procedure-related complications were documented. Additionally, the radiation dose was compared between obese (body mass index $\geq 30 \mathrm{~kg} / \mathrm{m}^{2}$ ) and non-obese patients. Results: Bilateral RDN was performed in 50/53 (94\%) cases and with a minimum of 4 ablations per artery in $33 / 50$ (66\%), the mean count being 5.4 (range R: $2-13$ ) on the right and 4.3 (R: 1 $10)$ on the left. The FT and DAP decreased significantly over the first 12 procedures, reaching a steady state with a median FT of $11.2 \mathrm{~min}$ (R: $7.5-27)$ and a median DAP of $4796 \mathrm{cGy} \times \mathrm{cm}^{2}(\mathrm{R}$ : $1076-21371)$, resulting in an effective dose of $15.7 \mathrm{mSv}$. The median PT was $57 \mathrm{~min}$ (R: 40 - 70). Obese patients had a 3.3-fold higher radiation dose $(\mathrm{p}<0.001)$. We observed one severe spasm and one imminent respiratory depression, both resolved without sequelae.

Conclusion: For an experienced interventionalist, RDN has a short learning curve with a low risk profile. The radiation dose does not exceed that of other renal artery interventions, but is explicitly higher in obese patients, who account for a large portion of patients with refractory hypertension. 


\section{Introduction}

\section{7}

Arterial hypertension is a major risk factor for cardiovascular and neurovascular morbidity and mortality worldwide with a prevalence of about $40 \%$ and causes 7.5 million deaths every year [13]. However, the relevance of this condition, especially in individuals with concomitant risk factors (e.g. diabetes mellitus, dyslipidemia, or obesity), is often underestimated owing to its usually asymptomatic nature. Not even half of all affected patients receive adequate medication and monitoring $[3,4]$. On the other hand, the blood pressure levels of approximately $5-15 \%$ of all patients with hypertensive disease cannot be lowered to a normal range despite the use of various antihypertensive drugs and lifestyle modification. This condition is described as refractory hypertension, and a growing body of evidence suggests that it is caused by an increased sympathetic activation [5, 6]. In the $1940 \mathrm{~s}$ and $1950 \mathrm{~s}$, before the rise of the various pharmacological treatment options, thoracolumbar splanchnicectomy was performed to lower sympathetic tone and to treat malignant hypertension [7]. Endovascular renal denervation (RDN) is a novel technique for the non-surgical disabling of renal sympathetic efferent and afferent nerves, and it has shown promising shortterm clinical results with relevant lowering of blood pressure levels and other markers of a previously increased sympathetic tone in the first published multicentre studies [8-10]. The present study was conducted to analyze the data from the first 53 patients in respect of procedural details, complications, and radiation exposure.

\section{Materials and Methods}

$\nabla$

From Nov 2010 to Oct 2012, 53 consecutive patients underwent RDN. Diagnosis of refractory hypertension was confirmed by experienced specialists in the setting of a special focus clinic for refractory hypertension of the Department of Nephrology. The baseline characteristics of all treated patients are presented in - Table 1. The estimated glomerular filtration rate (eGFR) was determined using the 4-variable MDRD study equation [11]. Contraindications were implanted pacemakers or cardioverter defi-

Table 1 Demographic data for all patients who underwent renal denervation.

Tab. 1 Demografische Daten aller behandelten Patienten.

\begin{tabular}{|c|c|}
\hline \multicolumn{2}{|l|}{ demographic data } \\
\hline n (male/female) & $53(35 / 18)$ \\
\hline age (years) [mean (range)] & $59(38-76)$ \\
\hline $\begin{array}{l}\text { baseline systolic blood pressure }(\mathrm{mmHg}) \\
\text { [mean (range)] }\end{array}$ & $168(150-210)$ \\
\hline $\begin{array}{l}\text { baseline diastolic blood pressure }(\mathrm{mmHg}) \\
\text { [mean (range)] }\end{array}$ & $94(60-150)$ \\
\hline $\begin{array}{l}\text { eGFR }\left(\mathrm{ml} / \mathrm{min} / 1.73 \mathrm{~m}^{2}\right) \text { [mean }(95 \% \text { confidence } \\
\text { interval)] }\end{array}$ & $76.4(71.5-81.4)$ \\
\hline $\begin{array}{l}\text { amount of antihypertensive drugs [median } \\
\text { (range)] }\end{array}$ & $5(3-9)$ \\
\hline body mass index $\left(\mathrm{kg} / \mathrm{m}^{2}\right)$ [mean (range)] & $30.5(23.4-45.6)$ \\
\hline \multicolumn{2}{|l|}{ additional cardiovascular risk factors [n] } \\
\hline diabetes mellitus & $12(23 \%)$ \\
\hline coronary heart disease & $10(19 \%)$ \\
\hline dyslipidemia & $7(13 \%)$ \\
\hline
\end{tabular}

eGFR - estimated glomerular filtration rate brillators and a vessel diameter below $4 \mathrm{~mm}$, assessed in pre-interventional computed tomography or magnetic resonance angiography. All other contraindications introduced in the proof-of-principle study by Krum et al. were considered to be relative and were individually weighted for each patient [8]. All patients were thoroughly assessed before RDN and adequately cared for afterwards. They gave written informed consent after having been given detailed information about the procedure, its aim, and possible risks. Data analysis was approved by the responsible ethics committee.

\section{Anesthesia}

Since the short 2-min ablation intervals are very painful, 36 patients received morphine sulfate and midazolam for analgesia and sedation under adequate cardiocirculatory monitoring. The required amounts of medications were documented. After the intervention, patients were transferred to a hospital ward for monitoring. The remaining patients had general anesthesia and were transferred to the Post-Anesthesia Care Unit for a 2-hour stay after the intervention.

\section{Procedural technique}

The interventions were performed using a state-of-the-art angiography system with flat-panel detectors (46× Artis zee ceiling, $7 \times$ Axiom Artis, Siemens Healthcare, Erlangen, Germany) for pulsed fluoroscopy (7.5 images/s) or serial angiography at a rate of 2 images/s. Because of the patients' limited capacity to cooperate due to sedation, and to improve orientation on the basis of anatomic landmarks, only non-subtracted series were acquired. Unilateral transfemoral access was created for placing a $6 \mathrm{~F}$ sheath and after optional aortography a $6 \mathrm{~F}$ guiding catheter with either a LIMA (left internal mammary artery) or RDC (renal double curve) configuration (Boston Scientific, Natick, MA, USA) according to anatomy and the examiner's preference was introduced. A Y-piece with a sliding valve (Medex - Smiths Medical, St. Paul, MN, USA) was attached to the catheter, which was continuously flushed with heparinized saline. The tip of the guiding catheter was advanced into the renal artery for slow intra-arterial administration of $0.2 \mathrm{mg}$ nifedipine for spasm prophylaxis (alternatively use $100-200 \mu \mathrm{g}$ nitroglycerine) and $2000 \mathrm{IU}$ heparin for thrombosis prophylaxis. Next, the ablation catheter (Symplicity ${ }^{\circledR}$, Medtronic, Minneapolis, MN, USA) was advanced into the renal artery, where its tip was released by withdrawing the guiding catheter, allowing stepless torque adjustment for ensuring stable wall contact. The first ablation site usually was $5 \mathrm{~mm}$ proximal to the first major renal artery bifurcation, the last site approximately $5 \mathrm{~mm}$ distal to the renal artery origin. In between energy was applied at distances of $5 \mathrm{~mm}$ along the long axis of the artery, with circumferential, ideally $90^{\circ}$ rotation of the catheter tip. The impedance and temperature at the catheter tip were monitored while the Symplicity ${ }^{\circledR}$ generator delivered a controlled, low-power radiofrequency (RF) energy routine over 2 minutes with a maximum energy of 8 watts. The aim was to perform at least four RF ablations in each main renal artery. Each change in catheter position was checked and documented by serial angiography or storing individual fluoroscopy frames. Following completion of RF energy applications on one side, the procedure was repeated in the same way in the contralateral renal artery. Finally, the system was removed and the puncture site closed with a 6F Angio-Seal $^{\text {TM }}$ STS Plus (St. Jude Medical Inc., St. Paul, MN, USA). After treatment of the first 11 patients, all subsequent 42 procedures were performed by one interventionalist with more than 
five years of experience performing radiological interventions, including renovascular procedures, and who had not performed the first 11 procedures. With this change in interventionalist, the documentation of the number of successful ablations per artery and periprocedural complications was supplemented by systematic documentation and analysis of procedure time (PT; from femoral puncture to removal of the system, not including vessel closure), fluoroscopy time (FT), dose-area product (DAP), and amount of contrast medium used. On the basis of DAP, we estimated the approximate effective dose of the intervention using a conversion factor of $0.328 \mathrm{mSvGy}^{-1} \mathrm{~cm}^{-2}$ for abdominal angiography performed predominantly in posteroanterior projection with a tube current of $80 \mathrm{kV}$ and $0.9 \mathrm{~mm}$ copper filter thickness determined by Monte Carlo simulation according to Gosch et al. [12]. The thickness of the copper filter was $0.9 \mathrm{~mm}$ in the fluoroscopy mode and $0.1 \mathrm{~mm}$ in the serial angiography mode. To simplify the calculation of the approximate effective dose from the DAP, we used the higher conversion factor for the thicker copper filter, since fluoroscopy accounts for most of the examination time.

\section{Refurbished catheters}

Similar to other electrophysiological catheters, the Symplicity ${ }^{\circledR}$ catheter can be refurbished and used again. A total of eight catheters were refurbished by VANGUARD corp., Berlin, Germany and reused. The refurbishing process used by VANGUARD has been accredited for Germany and complies with all legal regulations as laid down in the joint guideline of the Robert Koch Institute and the Federal Institute for Drugs and Medical Devices (RKI/ BfArM Recommendation) for the reprocessing of medical devices as well as with the most recent version of the German Medical Devices Act (Medizinproduktegesetz, MPG) in conjunction with the Regulations Governing the Installation, Operation, Use, and Maintenance of Medical Devices (Medizinprodukte-Betreiberverordnung, MPBetreibV).

\section{Statistical analysis}

According to whether parameters were parametrically or nonparametrically distributed, we calculated mean or median values with appropriate measures of scatter. As the total FT and DAP decreased in the course of the study, total medians of all intervention-related parameters were supplemented by testing differences for 7 consecutive groups of 6 patients each using the KruskalWallis test for multiple independent samples. In a stepwise procedure for testing the groups against each other, the first group of each test was excluded in the next until the groups tested against each other no longer showed any statistically significant differences, which represents the steady state. Scatter plots were drawn for graphical analysis. DAP for obese and non-obese patients were compared with the Mann-Whitney test. Statistical significance was assumed at $\mathrm{p}<0.05$. Statistical analysis was performed using SPSS 19 (IBM, Corporation, Armonk, NY, USA).

\section{Results}

$\nabla$

\section{Technical success and procedural details}

Three of 53 patients had end-stage renal failure (with polycystic kidney disease, diabetic nephropathy and hypertensive vasculopathy, respectively) and were on dialysis. Another patient had

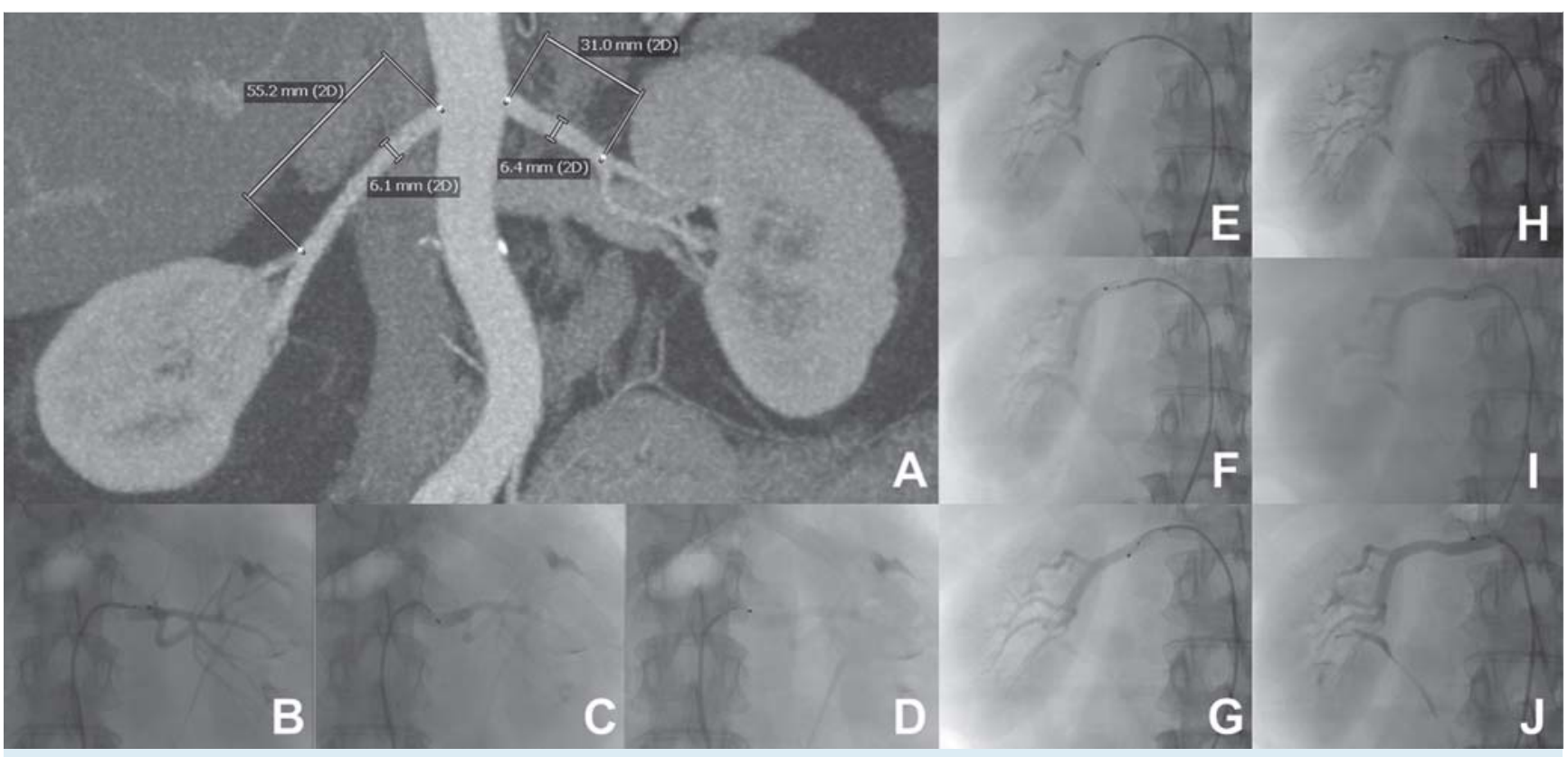

Fig. 1 Renal denervation in a patient with normal renal artery anatomy. a shows a coronal maximum intensity projection of pre-interventional computed tomography with favorable renal artery measurements. Distinct elongation of the infrarenal aorta and the pelvic arteries impaired stable positioning of the Symplicity ${ }^{\circledR}$ catheter in the shorter left renal artery, resulting in only three successful ablations $(\mathbf{b}-\mathbf{d})$. Six successful ablations were performed on the right side $(\mathbf{e}-\mathbf{j})$. The black dot at the tip of the catheter is the site of ablation; the second, smaller dot is the $5 \mathrm{~mm}$ marker to help ensure correct positioning.
Abb. 1 Renale Denervation bei einem Patienten mit normaler Nierenarterienanatomie. a zeigt die Abmessungen der Nierenarterien in einer koronaren Maximum-Intensitäts-Projektion. Die Elongation der infrarenalen Aorta sowie der Beckenachse erschwerten eine stabile Positionierung des Symplicity ${ }^{\circledR}$-Katheters links, weshalb lediglich 3 erfolgreiche Ablationen durchgeführt wurden (b-d). Rechts erfolgten 6 Ablationen (e-j). Der schwarze Punkt an der Spitze des Katheters entspricht der Stelle der Ablation, der zweite, kleinere Punkt entspricht einer 5mm-Markierung als Hilfe zur korrekten Positionierung. 


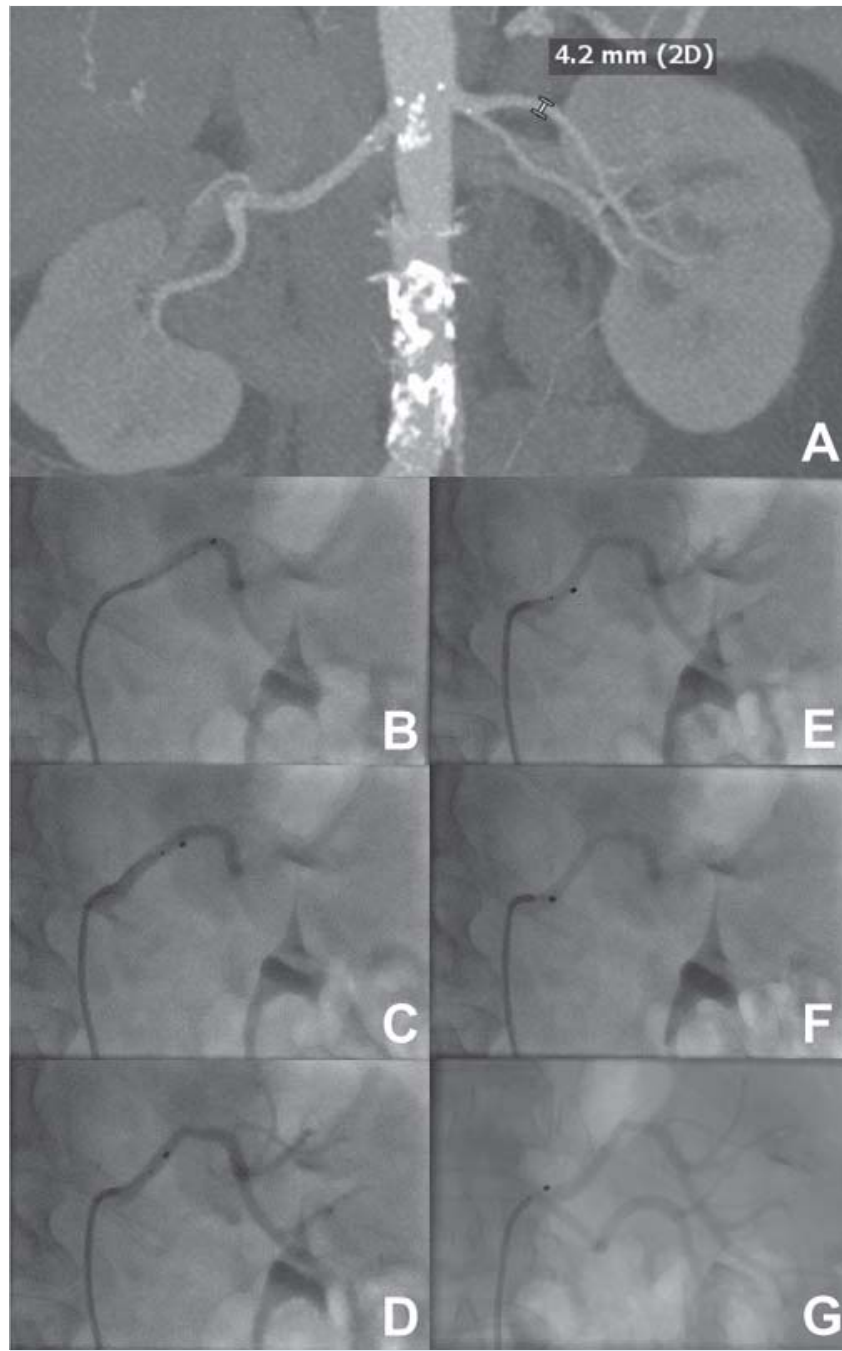

Fig. 2 Renal denervation in a patient with early bifurcation of the left renal artery. Computed tomography a confirms a sufficient vessel diameter (at least $4 \mathrm{~mm}$ ) in the upper branch. b-f show stepwise ablation of the upper branch, and $\mathbf{g}$ shows an additional ablation of the short main renal artery. Notice the moderate irregularity in the course of the upper branch after ablation resulting from minor spasm and/or vascular wall edema. On the right side with normal renal artery anatomy, eight ablations were successfully completed (not shown).

Abb. 2 Renale Denervation bei einem Patienten mit früher Aufzweigung der linken Nierenarterie. Die Computertomografie a bestätigt einen hinreichenden Diameter des oberen Astes von $>4 \mathrm{~mm}$. b-f zeigen die schrittweise Ablation des oberen Astes und $\mathbf{g}$ stellt eine zusätzliche Ablation des kurzen Hauptstamms der Nierenarterie dar. Deutlich erkennbar sind die unmittelbar postinterventionellen Wandunregelmäßigkeiten infolge geringer Spasmen und/oder bedingt durch Wandödeme. Rechtsseitig erfolgten bei normaler Nierenarterienanatomie 8 erfolgreiche Ablationen (nicht abgebildet).

chronic renal failure with compensated retention and an eGFR of $27.7 \mathrm{ml} / \mathrm{min} / 1.73 \mathrm{~m}^{2}$. In this case the amount of contrast medium was reduced to $50 \mathrm{ml}$ and the patient was adequately hydrated before and after the procedure. He did not show any worsening of renal function after RDN. All other patients had adequate renal function with a mean eGFR of $76.4 \mathrm{ml} / \mathrm{min} / 1.73 \mathrm{~m}^{2}$ (95\% confidence interval: 71.5 - 81.4).

Bilateral ablation was performed in 50/53 cases (94\%); 33/50 patients $(66 \%)$ with bilateral ablation had at least four ablations on

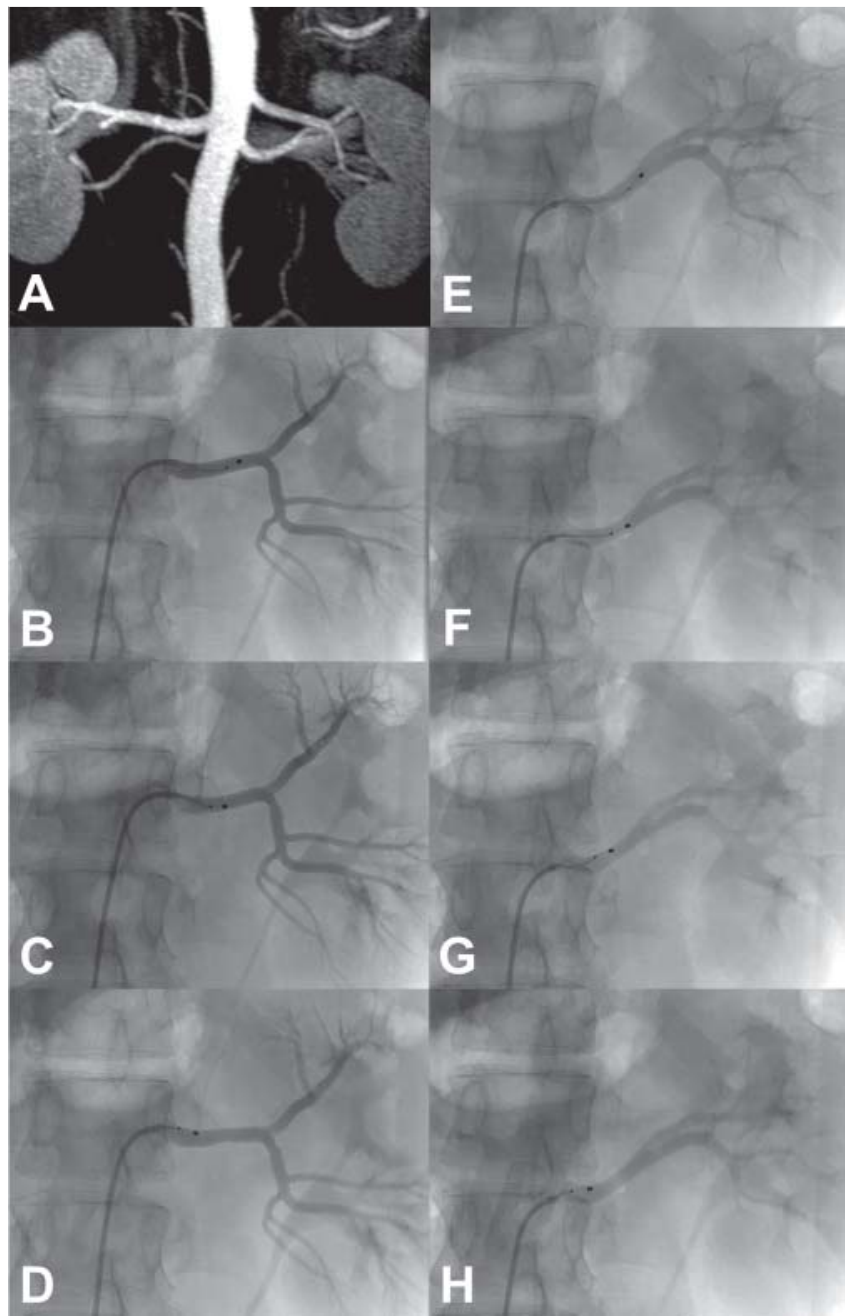

Fig. 3 Patient with renal denervation of two main renal arteries on the left side. MR angiography a shows two large main renal arteries on the left side and one on the right side with an additional inferior pole artery. Successful denervation of both the left upper anterior renal artery $\mathbf{b}$ - $\mathbf{d}$ and the lower posterior renal artery $\mathbf{e}-\mathbf{h}$ is shown. On the right side three ablations of the main renal artery were successfully performed (not shown).

Abb.3 Renale Denervation zweier Nierenarterien links. Die MR-Angiographie a zeigt die 2 kräftigen Nierenarterien links sowie eine Hauptarterie und eine zusätzliche untere Polarterie rechts. Beide linksseitigen Nierenarterien wurden erfolgreich behandelt, die obere anteriore $\mathbf{b}$ - $\mathbf{d}$ und die untere posteriore $\mathbf{e}-\mathbf{h}$. Rechtsseitig erfolgten 3 erfolgreiche Ablationen (nicht abgebildet).

each side. In one patient, a total of three renal arteries were treated. The mean number of ablations per side was 5.4 on the right (range: $2-13$ ) and 4.3 on the left (range: 1 -10). 0 Fig. 1 - 3 illustrate three cases of renal artery denervation with a typical anatomy, an early renal artery bifurcation, and two main renal arteries, respectively. Unilateral RDN was performed in three cases for the following reasons. In one case, the intervention had to be discontinued after successful unilateral ablation owing to difficult-to-control analgesia and sedation, with imminent respiratory and cardiocirculatory depression. Another patient had a double renal artery on one side with both arteries being too thin for ablation $(<4 \mathrm{~mm})$. Unilateral denervation was performed in this case because the patient urgently required treatment. A third patient had already undergone a nephrectomy on the left side. 


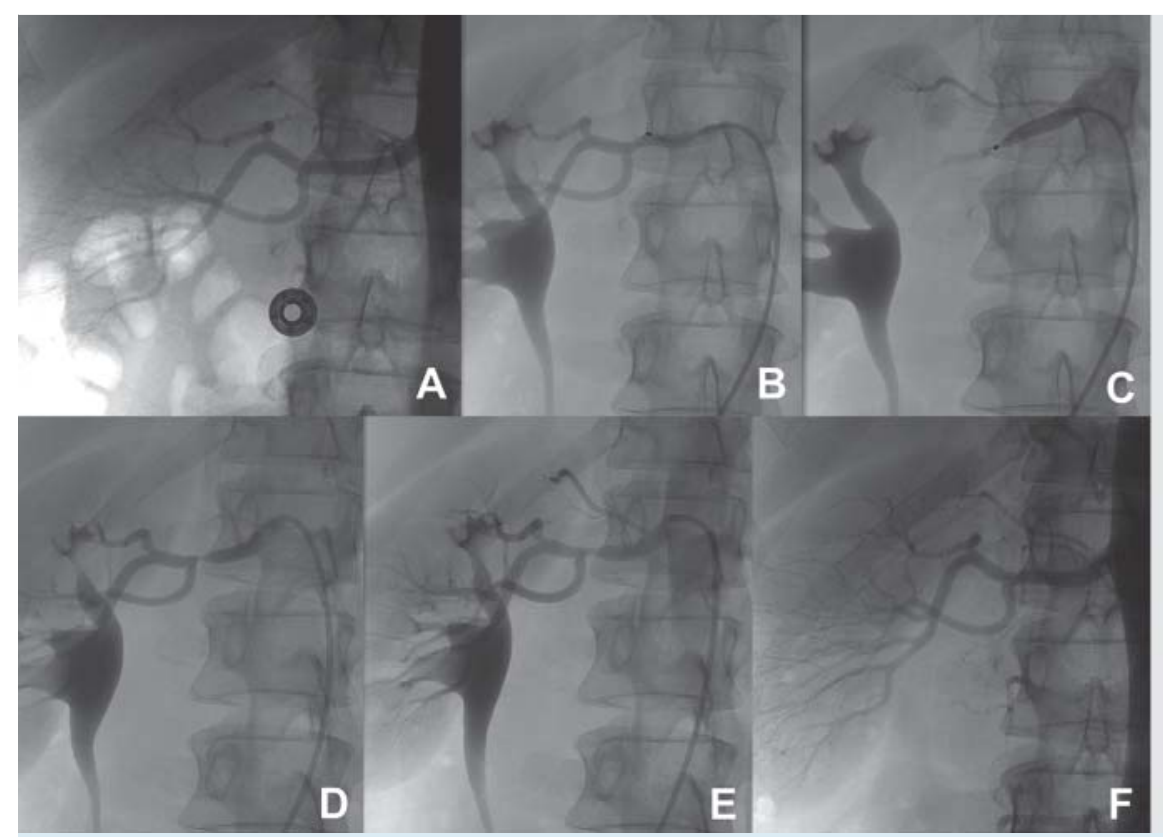

Fig. 4 Severe renal artery spasm during renal denervation. a shows normal renal artery anatomy on the right side, suitable for renal denervation. The position of the catheter tip was checked before ablation $\mathbf{b}$. During ablation the temperature at the tip of the catheter suddenly rose to $70^{\circ}$. The cycle was discontinued manually, and angiography confirmed occluding spasm around the catheter tip, precluding cooling blood flow $\mathrm{c}$. The catheter was removed and $0.2 \mathrm{mg}$ nifedipine and $2 \mathrm{ml}$ lidocaine $2 \%$ were slowly injected. After 20 min the spasm was still severe $\mathbf{d}$. Additional angioplasty with a $3 \times 20 \mathrm{~mm}$ balloon restored a hemodynamically acceptable situation despite residual stenosis e. Three months later the spasm had completely resolved and no residual stenosis was evident $\mathbf{f}$.
Abb. 4 Ausgeprägter Spasmus der rechten Nierenarterie unter renaler Denervation. a zeigt eine normal erscheinende rechte Nierenarterie vor Ablation. Die Lage des Katheters wurde vor Start der ersten Ablation überprüft b. Unter dieser stieg die Temperatur plötzlich auf $70^{\circ}$. Der Zyklus wurde manuell abgebrochen und eine Kontrollangiografie bestätigte einen okklusiven Spasmus um die Katheterspitze, weshalb die Kühlung der Spitze ausblieb c. Der Ablationskatheter wurde entfernt und $0,2 \mathrm{mg}$ Nifedipin sowie $2 \mathrm{ml}$ Lidocain $2 \%$ langsam injiziert. d zeigt den nach 20 min noch immer hochgradigen Spasmus. Mittels vorsichtiger ergänzender Angioplastie mit einem $3 \times 20 \mathrm{~mm}$ messenden Ballon konnte eine hämodynamisch akzeptable Situation hergestellt werden e. Drei Monate später hat sich der Spasmus ohne residuelle Stenose zurückgebildet $\mathbf{f}$.
We used a median amount of $100 \mathrm{ml}$ (range: 45 -170) contrast medium during the procedure.

In two interventions, catheter malfunction occurred after 1-2 successful ablations. In these situations, the catheter tip did not heat up, despite good wall contact. The respective cycle was discontinued automatically by the generator. New catheters were introduced without further problems; the malfunctioning catheters were returned to the manufacturer, and defective electrical contacts were confirmed.

In 36 patients, we accomplished renal sympathetic denervation under analgesia and sedation with morphine sulfate and midazolam. The mean amounts were $14.9 \mathrm{mg}$ each, administered in small incremental doses under adequate cardiocirculatory monitoring.

\section{Complications and adverse events}

We observed periprocedural complications in 2/53 (4\%) patients. One of these patients experienced imminent respiratory and cardiocirculatory depression due to analgosedation after successful ablation of one artery. The intervention and analgosedation were discontinued immediately.

In the second case ( $\bullet$ Fig. 4 ), we failed to accomplish bilateral ablation due to severe spasm during the first ablation in the right renal artery. The temperature suddenly increased from $52-70^{\circ}$ $\mathrm{C}$ and ablation was immediately discontinued. Only moderate resolution of the spasm was observed, despite slow intra-arterial administration of another $0.2 \mathrm{mg}$ of nifedipine and $2 \mathrm{ml}$ of $2 \%$ lidocaine and a 20-min wait during which the contralateral ar- tery was ablated. Finally, we carefully dilated the artery with a $3 \times 20 \mathrm{~mm}$ balloon catheter, resulting in approximately $50 \%$ residual narrowing. The residual stenosis showed no hemodynamic relevance in angiography and Doppler ultrasound follow-up examinations performed over the following three days. Bilateral RDN was completed three months later after full resolution of the spasm-induced stenosis, resulting in a total of 4 ablations on that side. This secondary intervention was not included in the analysis.

Mild, hemodynamically irrelevant wall irregularities corresponding to small local spasms or circumscribed wall edema were consistently seen after ablation, but not generally counted as a complication. There was no case of persistent damage.

\section{Radiation exposure}

This was documented for patients $12-53$ (see Methods). The median PT was $60 \mathrm{~min}$ (range: 40-95), median FT $12.7 \mathrm{~min}$ (range: $7.5-28.2$ ), and median DAP $6754 \mathrm{cGY} \times \mathrm{cm}^{2}$ (range: 1076 - 64570). From the median DAP, the approximate effective dose was calculated and found to be $22.2 \mathrm{mSv}$. The "learning curve" of the interventionalist was assessed by scatter plots and by comparing consecutive groups of patients. A significant decrease was seen in both the DAP and FT up to the 12th intervention, after which a steady state was reached ( $\bullet$ Fig. $\mathbf{5}-\mathbf{7}$ ). For the steady state, the median PT was 57 min (range: 40 - 70), median FT 11.2 min (range: $7.5-27$ ), and median DAP $4796 \mathrm{cGY} \times \mathrm{cm}^{2}$ (range: 1076 - 21371 ), which corresponds to an approximate ef- 


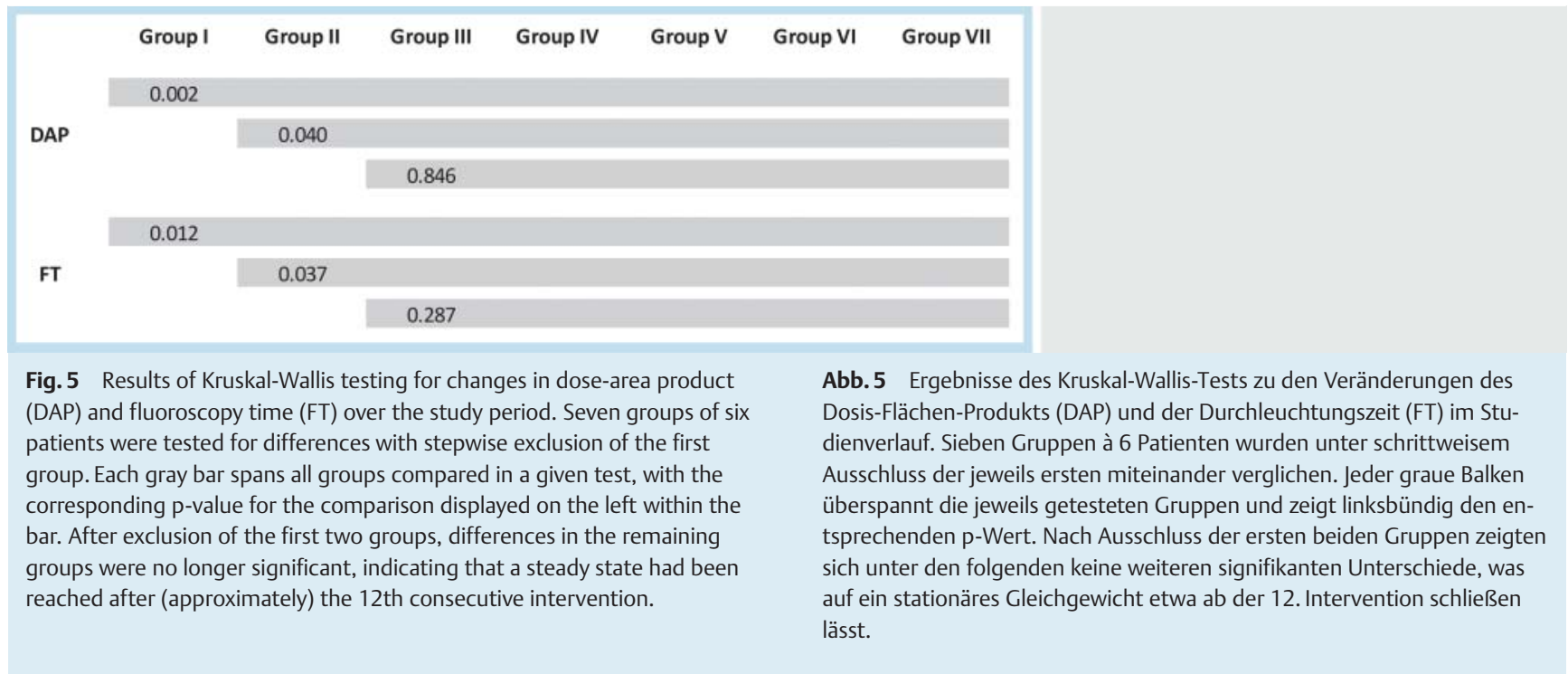

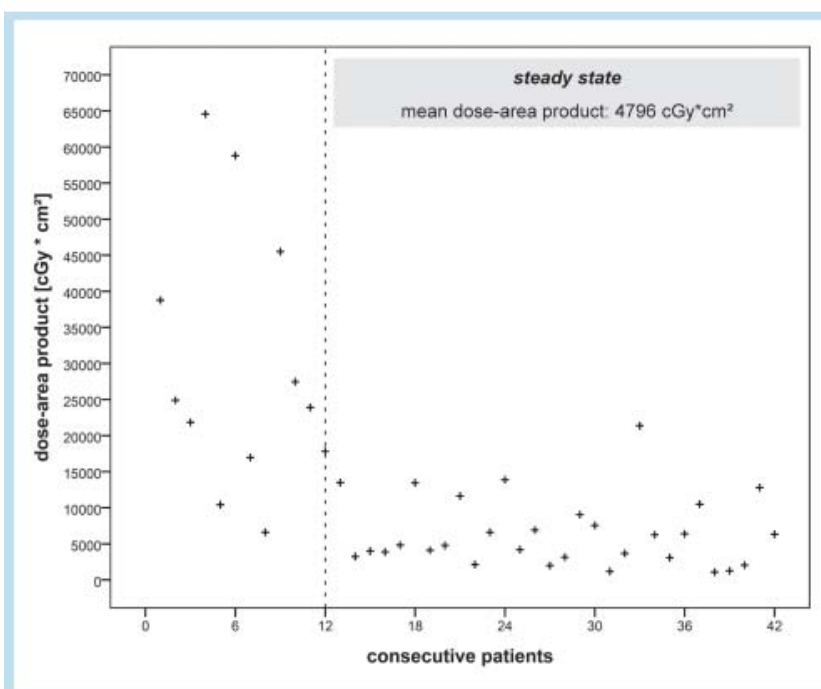

Fig. 6 Scatter plot showing the dose-area product per patient in consecutive order. According to Kruskal-Wallis testing (Fig. 5), the radiation dose significantly decreased until the 12th intervention (vertical discontinuous line) to a steady state with a median of $4796 \mathrm{cGy} \times \mathrm{cm}^{2}$ (range: 1076 21371).

Abb. 6 Streudiagramm zum Dosis-Flächen-Produkt je Patient in konsekutiver Reihenfolge. Entsprechend der Kruskal-Wallis-Analyse (Abb. 5) sank die Strahlendosis signifikant bis zur 12. Intervention (vertikale gestrichelte Linie) auf ein stationäres Gleichgewicht von im Median $4796{\mathrm{cGy} \times \mathrm{cm}^{2}}^{2}$ (Spannweite: 1076 - 21371).

fective dose of $15.7 \mathrm{mSv}$. The radiation dose was also markedly influenced by the patient's body mass index (BMI) as more than half of the patients $\left(28 / 53 ; 53 \%\right.$ ) had a BMI of $30 \mathrm{~kg} / \mathrm{m}^{2}$ or more. Patients with a BMI of less than $30 \mathrm{~kg} / \mathrm{m}^{2}$ (median [range]: 26.1 [23.4-29.8]) received a significantly $(p<0.001)$ lower median dose of $4148.5 \mathrm{cGY} \times \mathrm{cm}^{2}$ (range: $1076-13472$ ) compared with $13666 \mathrm{cGy \times \textrm {cm } ^ { 2 }}$ (range: $1985-64570$ ) for patients with a BMI above $30 \mathrm{~kg} / \mathrm{m}^{2}$ (median [range]: 34.0 [30.0-45.6]). The corresponding estimated median effective dose is $13.6 \mathrm{mSv}$ for patients with a BMI below $30 \mathrm{~kg} / \mathrm{m}^{2}$ and $44.8 \mathrm{mSv}$ for those with a BMI above $30 \mathrm{~kg} / \mathrm{m}^{2}$.

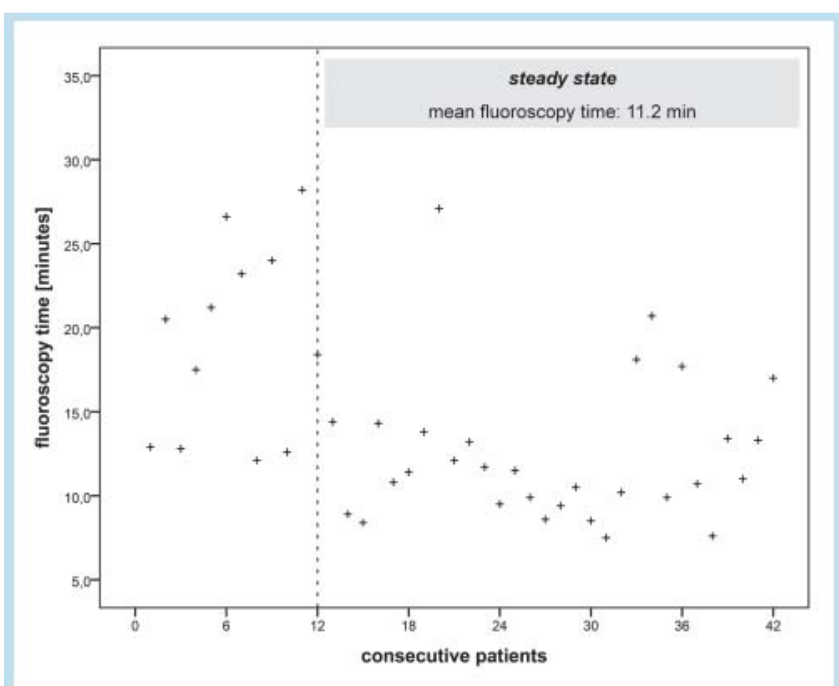

Fig. 7 Scatter plot showing the fluoroscopy time per patient in consecutive order. According to Kruskal-Wallis testing (Fig. 5), the fluoroscopy time significantly decreased until the 12 th intervention (vertical discontinuous line) to a steady state with a median of 11.2 minutes (range: $7.5-27$ ).

Abb. 7 Streudiagramm zur Durchleuchtungszeit je Patient in konsekutiver Reihenfolge. Entsprechend der Kruskal-Wallis Analyse (Abb. 5) sank die Durchleuchtungszeit signifikant bis zur 12. Intervention (vertikale gestrichelte Linie) auf ein stationäres Gleichgewicht von im Median 11,2 min (Spannweite: 7,5-27).

\section{Refurbished catheters}

Similar to other electrophysiological catheters, the Symplicity ${ }^{\circledR}$ catheter can be refurbished and used again. We used a total of eight refurbished catheters - six catheters that were refurbished once and two that were refurbished twice. We did not encounter technical difficulties with these catheters during the ablation process. However, each passage through the often elongated and severely kinked iliac arteries stresses the catheter at its weakest point, i.e., the abrupt transition from the very stiff shaft to the $10 \mathrm{~cm}$ long floppy end, until it breaks ( $\mathbf{F i g . 8}$ ). Conventional guiding catheters are not able to straighten up the vessel enough 


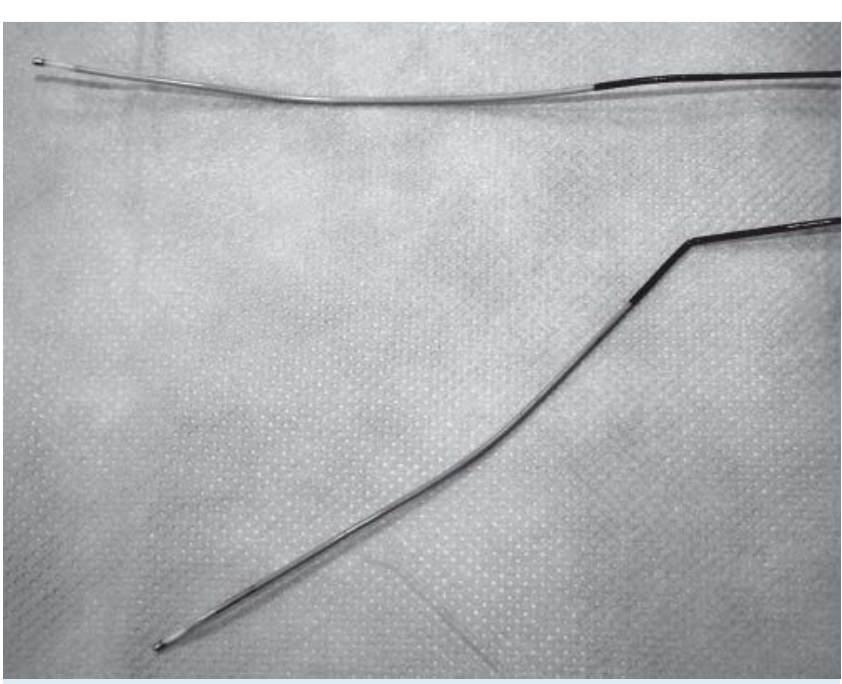

Fig. 8 Tip of a new unused Symplicity ${ }^{\circledR}$ catheter and below a catheter that was refurbished twice and broke at the transition from the very stiff shaft to the $10 \mathrm{~cm}$ long floppy end due to repeated stress by several passages through elongated iliac arteries.

Abb. 8 Spitze eines neuen, ungebrauchten Symplicity ${ }^{\circledR}$-Katheters und darunter eines 2-fach wiederaufbereiteten Katheters, der infolge wiederholter Passagen durch elongierte Beckenarterien an der Übergangszone vom steifen Schaft zur $10 \mathrm{~cm}$ langen flexiblen Spitze brach.

to reduce friction when inserting the ablation catheter, especially when used in combination with the standard short and stiff $6 \mathrm{~F}$ sheath, which rectifies the distal segment of the iliac elongation but at the cost of increasing kinking proximally. Therefore, we started to use 25 to $35 \mathrm{~cm}$ long sheaths (Super Arrow-Flex ${ }^{\circledR}, \mathrm{Ar}$ row Int., Reading, PA, USA or Radiofocus ${ }^{\circledR}$ Introducer II, Terumo Medical Corp., Somerset, NJ, USA), which markedly reduced the stress on the catheter.

\section{Discussion \\ $\nabla$}

The sympathetic nerves within the adventitia of the renal arteries are believed to modulate central sympathetic activity, and their hyperactivation causes and maintains arterial hypertension $[5,13]$. RDN was introduced to regulate sympathetic hyperactivity by thermal ablation of large portions of these nerves from within the artery. Initial clinical experience in a proof-of-principle cohort and the first randomized controlled trial showed encouraging short-term effects $[8,10]$. In consequence, in spite of the relatively few published results, this procedure is already the subject of several reviews (e.g. 14, 15) and is of increasing interest to clinicians responsible for patients with refractory hypertension. However, little has been published about procedural details, which may be of interest for any interventionalist starting to perform this procedure [16].

\section{Radiation exposure}

Our analysis shows that an interventional radiologist with average renovascular intervention experience becomes familiar with the procedure after only a few cases. Initially, it is primarily more frequent monitoring of catheter positions that contributes to the longer FT and higher DAP. As the interventionalist's experience increases, the patient's radiation dose is reduced by the use of fewer repeat serial angiograms in favor of short, pulsed fluoroscopies without unnecessary magnification and greater reliance on temperatures and resistances measured via the catheter. Preinterventional cross-sectional imaging, either computed tomography or magnetic resonance imaging, is helpful for ruling out renal artery stenosis or other secondary causes of hypertension before RDN and for appropriate case planning to prepare for possibly difficult anatomy and thus a lower FT (17 - 19). While these technical factors that influence the radiation dose can be controlled, there are also patient-related factors that increase the required radiation dose. Many candidates for ablation treatment are obese, which does not greatly impair image quality in the setting of RDN but increases the necessary radiation dose markedly. The patients in the Symplicity HTN-2 trial had a mean BMI of $31 \mathrm{~kg} / \mathrm{m}^{2}$; in our study population, $28 / 53$ patients had a BMI of $30 \mathrm{~kg} / \mathrm{m}^{2}$ or more. These subjects had a 3.3-fold higher radiation dose compared with normal-weight and pre-obese patients. In a phantom simulation of $\mathrm{X}$-ray examinations, Yanch et al. even found up to 83 times higher doses for obese patients depending on the amount and distribution of simulated fat tissue [20]. Hence, it is important to pay special attention to radiation protection for both the patient and the staff performing the intervention.

A higher radiation dose also results when an intervention is more complex, for instance when arteries have become elongated in long-standing hypertension. Probing and stable positioning of the ablation catheter can be more difficult in these cases.

Once the interventionalist was familiar with the procedure, we achieved a DAP of $4796 \mathrm{cGY}^{*} \mathrm{~cm}^{2}$ (range: 1076 - 21 371) and a liberally estimated effective dose of $15.7 \mathrm{mSv}$, which is within the range of published dose levels for renal artery angiographic procedures. Bor et al. reported a dose of $7300 \mathrm{cGY} \times \mathrm{cm}^{2}$ (range: $2520-17150$ ) for purely diagnostic angiographies of the renal arteries performed with a somewhat older angiography system, while Topaltzikis et al. estimated the mean effective dose of diagnostic angiographies to be $15.9 \mathrm{mSv}$ (range: 5.3 - 32.6) [21, 22].

\section{Complications}

Very few complications and adverse events have been published. For the expanded cohort of the Symplicity HTN-1 study, a complication rate of $5 \%$ was reported. The observed complications included one renal artery dissection, prompting renal artery stenting, three inguinal pseudoaneurysms and four cases of postprocedural temporary flank pain. In the setting of the Symplicity HTN-2 study, the percentage of adverse events was $10 \%$ with one case each of pseudoaneurysm, urinary tract infection, post-therapeutic hypotension, temporary paresthesia, and flank pain. We observed one severe arterial spasm and one imminent respiratory and cardiocirculatory depression in a patient with obstructive sleep apnea syndrome (OSAS). On the basis of this experience, we decided that patients with OSAS or other respiratory impairments should preferably be treated under general anesthesia.

\section{Pain control}

As in other percutaneous radiofrequency ablations, energy application causes severe visceral pain. We used morphine sulfate and midazolam for analgosedation. Our regimen was more sedative than the one used in the Symplicity HTN-1 study, which consisted of administration of a comparable amount of morphine sulfate with a mean dose of $18.4 \mathrm{mg}$, but only $4.2 \mathrm{mg}$ midazolam [8]. While this combination is widely used, there are some risks for which the interventionalist must be prepared [23]. Current study reports additionally describe the occurrence of bradycardia 
requiring treatment (atropine) in up to $13 \%$ of cases. No bradycardia was observed in our study. In our experience, general anesthesia, which we initially only used for OSAS patients, considerably simplifies the procedure, as we did not see deep respiratory movements or rearing up of the patients due to poorly controlled pain under sedation. While this made the positioning of the catheter easier and more stable, it also increases the costs of the procedure.

\section{Limitations}

The limitations of the present study were the small number of patients, especially in view of the fact that detailed procedural data were not acquired until patient 12 . However, the analysis confirmed a steady state already after 12 procedures, meaning that the inclusion of more patients in this study would not have been needed. Additionally, procedures differed in terms of pain control: while the majority of patients were treated under analgosedation, a large number received general anesthesia. However, graphical analysis of the DAP and FT did not show a relevant trend for the last 16 patients treated exclusively under general anesthesia.

\section{Conclusion}

We conclude that RDN is technically safe and easy to learn for an interventionalist with average experience. After twelve procedures no further significant reduction in FT and DAP was achieved and the radiation dose was comparable to that of other renovascular interventions. The higher prevalence of obese patients in this population demands special awareness of radiation protection, not only for the patient but also for the staff conducting the procedure. In patients with an abnormal renal artery anatomy (e.g., early bifurcation, doubled main renal artery), RDN is technically feasible as long as the vessel diameter is at least $4 \mathrm{~mm}$. However, a clear clinical benefit remains to be established for these patients and clinical trials will have to show whether or not this weakens the therapeutic effect demonstrated in the Symplicity HTN trials.

\section{References}

1 Lewington S, Clarke R, Qizilbash $N$ et al. Age-specific relevance of usual blood pressure to vascular mortality: a meta-analysis of individual data for one million adults in 61 prospective studies. The Lancet 2002; 360: 1903 - 1913

2 Kearney PM, Whelton M, Reynolds $K$ et al. Global burden of hypertension: analysis of worldwide data. The Lancet 2005; 365: 217-223

3 Roger VL, Go AS, Lloyd-Jones DM et al. Heart Disease and Stroke Statistics - 2011 Update. Circulation 2011; 123: e18 - e209

4 Kjeldsen SE, Naditch-Brule L, Perlini S et al. Increased prevalence of metabolic syndrome in uncontrolled hypertension across Europe: the
Global Cardiometabolic Risk Profile in Patients with hypertension disease survey. J Hypertens 2008; 26: 2064-2070

5 DiBona GF. Sympathetic nervous system and the kidney in hypertension. Curr Opin Nephrol Hypertens 2002; 11: 197-200

6 Grassi G, Bertoli S, Seravalle G. Sympathetic nervous system: role in hypertension and in chronic kidney disease. Curr Opin Nephrol Hypertens 2012; 21: 46-51

7 Smithwick RH, Thompson JE. Splanchnicectomy for essential hypertension; results in 1,266 cases. J Am Med Assoc 1953; 152: 1501 - 1504

8 Krum H, Schlaich M, Whitbourn R et al. Catheter-based renal sympathetic denervation for resistant hypertension: a multicentre safety and proof-of-principle cohort study. Lancet 373 (2009): 1275-1281

9 Symplicity HTN-1 Investigators. Catheter-Based Renal Sympathetic Denervation for Resistant Hypertension: Durability of Blood Pressure Reduction out to 24 Months. Hypertension. 2011; 57: 911 -917

10 Esler MD, Krum H, Sobotka PA et al. Renal sympathetic denervation in patients with treatment-resistant hypertension (The Symplicity HTN-2 Trial): a randomised controlled trial. Lancet 2010; 376: $1903-$ 1909

11 Levey AS, Coresh J, Greene T et al. Using Standardized Serum Creatinine Values in the Modification of Diet in Renal Disease Study Equation for Estimating Glomerular Filtration Rate. Ann Intern Med 2006; 145: $247-254$

12 Gosch D, Gosch K, Kahn T. Konversionsfaktoren zur Ermittlung der effektiven Dosis für Patienten aus dem Dosisflächenprodukt in Röntgendurchleuchtungsuntersuchungen. Fortschr Röntgenstr 2007; 179: $1035-1042$

13 Esler M, Jennings G, Korner $P$ et al. Assessment of human sympathetic nervous system activity from measurements of norepinephrine turnover. Hypertension 1988; 11: 3-20

14 Doumas M, Faselis C, Papademetriou V. Renal sympathetic denervation and systemic hypertension. Am J Cardiol 2010; 105: 570-576

15 Uder M, Schmid A, Titze S et al. Renal artery denervation for the treatment of hypertension: opening up new horizons. Cardiovasc Intervent Radiol 2011; 34: 442 - 444

16 Sapoval M, Azizi M, Bobrie G et al. Endovascular Renal Artery Denervation: Why, When, and How? CardioVascular and Interventional Radiology 2012 ; 35: 463-471

17 Pei Y, Shen H, Li J et al. Evaluation of Renal Artery in Hypertensive Patients by Unenhanced MR Angiography Using Spatial Labeling With Multiple Inversion Pulses Sequence and by CT Angiography. Am J Roentgenol 2012; 199: $1142-1148$

18 Lüdemann L, Nafz B, Elsner $F$ et al. Dependence of renal blood flow on renal artery stenosis measured using CT angiography. Fortschr Röntgenstr 2011; 183: 267-273

19 Lanzman RS, Schmitt $P$, Kröpil $P$ et al. Techniken der kontrastmittelfreien MR-Angiografie. Fortschr Röntgenstr 2011; 183: 913-924

20 Yanch JC, Behrman RH, Hendricks MJ et al. Increased Radiation Dose to Overweight and Obese Patients from Radiographic Examinations1. Radiology 2009; 252: 128 - 39

21 Bor D, Toklu T, Olğar T et al. Variations of patient doses in interventional examinations at different angiographic units. Cardiovasc Intervent Radiol 2006; 29: 797-806

22 Topaltzikis T, Rountas C, Fezoulidis I et al. In vivo dosimetry during DSA of the carotid and renal arteries. Deriviation of local DRLs. Phys Med 2009; 25: 166-171

23 American Society of Anesthesiologists Task Force on Sedation and Analgesia by Non-Anesthesiologists. Practice guidelines for sedation and analgesia by non-anesthesiologists. Anesthesiology 96 (2002): $1004-$ 1017 